\title{
PENGARUH KONDISI ATMOSFERIK TERHADAP PERHITUNGAN PROBABILISTIK DAMPAK RADIOLOGI KECELAKAAN PWR 1000-MWE
}

\author{
Pande Made Udiyani, Sri Kuntjoro \\ Pusat Teknologi dan Keselamatan Reaktor Nuklir, BATAN \\ email: pmade-u@batan.go.id, telp: 021-7560912,fax: 021-7560913 \\ Diterima editor: 1 September 2015 \\ Direvisi editor: 9 September 2015 \\ Disetujui untuk publikasi: 23 September 2015
}

\begin{abstract}
ABSTRAK
PENGARUH KONDISI ATMOSFERIK TERHADAP PERHITUNGAN PROBABILISTIK DAMPAK RADIOLOGI KECELAKAAN PWR 1000-MWe. Perhitungan dampak kecelakaan radiologi terhadap lepasan produk fisi akibat kecelakaan potensial yang mungkin terjadi di Pressurized Water Reactor (PWR) diperlukan secara probabilistik. Mengingat kondisi atmosfer sangat berperan terhadap dispersi radionuklida di lingkungan, dalam penelitian ini akan dianalisis pengaruh kondisi atmosferik terhadap perhitungan probabilistik dari konsekuensi kecelakaan reaktor. Tujuan penelitian adalah melakukan analisis terhadap pengaruh kondisi atmosfer berdasarkan model data input meteorologi terhadap dampak radiologi kecelakaan PWR 1000-MWe yang disimulasikan pada tapak yang mempunyai kondisi meteorologi yang berbeda. Simulasi menggunakan program PC-Cosyma dengan moda perhitungan probabilistik, dengan data input meteorologi yang dieksekusi secara cyclic dan stratified, dan disimulasikan di Tapak Semenanjung Muria dan Pesisir Serang. Data meteorologi diambil setiap jam untuk jangka waktu satu tahun. Hasil perhitungan menunjukkan bahwa frekuensi kumulatif untuk model input yang sama untuk Tapak pesisir Serang lebih tinggi dibandingkan dengan Semenanjung Muria. Untuk tapak yang sama, frekuensi kumulatif model input cyclic lebih tinggi dibandingkan model stratified. Model cyclic memberikan keleluasan dalam menentukan tingkat ketelitian perhitungan dan tidak membutuhkan data acuan dibandingkan dengan model stratified. Penggunaan model cyclic dan stratified melibatkan jumlah data yang besar dan pengulangan perhitungan akan meningkatkan ketelitian nilai-nilai statistika perhitungan.
\end{abstract}

Kata kunci: dampak kecelakaan, PWR 1000-MWe, probabilistik, atmosferik, PC-Cosyma

\section{ABSTRACT}

THE INFLUENCE OF ATMOSPHERIC CONDITIONS TO PROBABILISTIC CALCULATION OF IMPACT OF RADIOLOGY ACCIDENT ON PWR-1000MWe. The calculation of the radiological impact of the fission products releases due to potential accidents that may occur in the PWR (Pressurized Water Reactor) is required in a probabilistic. The atmospheric conditions greatly contribute to the dispersion of radionuclides in the environment, so that in this study will be analyzed the influence of atmospheric conditions on probabilistic calculation of the reactor accidents consequences. The objective of this study is to conduct an analysis of the influence of atmospheric conditions based on meteorological input data models on the radiological consequences of PWR-1000MWe accidents. Simulations using PCCosyma code with probabilistic calculations mode, the meteorological data input executed cyclic and stratified, the meteorological input data are executed in the cyclic and stratified, and simulated in Muria Peninsula and Serang Coastal. Meteorological data were taken every hour for the duration of the year. The result showed that the cumulative frequency for the same input models for Serang coastal is higher than the Muria Peninsula. For the same site, cumulative frequency on cyclic input models is higher than stratified models. The cyclic models provide flexibility in determining the level of accuracy of calculations and do not require reference data compared to stratified models. The use of cyclic and stratified models involving large amounts of data and calculation repetition will improve the accuracy of statistical calculation values.

Keywords: accident impact, PWR 1000 MWe, probabilistic, atmospheric, PC-Cosyma 


\section{PENDAHULUAN}

Konsekuensi dari lepasan zat radioaktif (ZRA) ke lingkungan akibat terjadinya kecelakaan Pembangkit Listrik tenaga Nuklir (PLTN) akan mengakibatkan dampak terhadap masyarakat dan lingkungan. Perhitungan dampak kecelakaan radiologi terhadap lepasan produk fisi akibat kecelakaan potensial yang mungkin terjadi di PWR diperlukan secara deterministik maupun probabilistik. Kajian risiko probabilistik Probabilistic Risk Assessment (PRA) atau kajian konsekuensi kecelakaan Accident Consequences Assessment (ACA) adalah proses dimana konsekuensi potensial dari lepasan radionuklida dianalisis, dengan mempertimbangkan berbagai kondisi yang mungkin berlaku pada saat kecelakaan dan kemungkinan terkait kondisi tersebut. Perhitungan dilakukan menggunakan analisis probabilistik, dengan konsekuensi kejadian yag ada dalam suatu daerah dengan berbagai kondisi (range of conditions). Setiap pasang kondisi yang dipertimbangkan merupakan satu probabilitas kejadian, maka setiap pasang nilai berhubungan dengan setiap kebolehjadian. Dengan memilih opsi probabilistik dari program PCCosyma digunakan untuk memberikan informasi pada distribusi probabilistik dari suatu konsekuensi yang terjadi pada suatu populasi akibat kecelakaan [1]. Analisis yang menggunakan konsep PRA pada metode Probabilistic Safety Assessment (PSA) Level-3 telah banyak dilakukan oleh peneliti analisis keselamatan PLTN lainnya [2,3].

Metode lain juga dilakukan untuk menghitung konsekuensi secara deterministik maupun probabilistik dengan menggunakan program SYMBIOSE [4]. Tidak berbeda dengan PCCosyma, simulasi analisis konsekuensi program tersebut juga memerlukan data input source term, meteorologi, kontur tapak, populasi penduduk, dan data lingkungan lainnya. Program yang sejenis juga banyak digunakan seperti program Hybrid Single Particle Lagrangian Integrated Trajectory (HYSPLIT) yang menggunakan model Larangian dalam perhitungan dispersi [5]. Belajar dari pengalaman Fukushima, kajian terhadap konsekuensi lepasan radionuklida masih terus dilakukan. Walaupun dasar perhitungan menggunakan model atau program yang sama, tetapi karena konsekuensi radiasi ke lingkungan dipengaruhi oleh banyak faktor seperti besarnya source term, parameter dispersi, kondisi meteorologi dan kondisi lingkungan lokal tapak reaktor [6]. Kondisi atmosferik adalah faktor kritikal dalam menentukan distribusi spasial dari dispersi radionuklida [7], maka dalam penelitian ini akan dikaji dan dianalisis pengaruh kondisi atmosferik terhadap perhitungan probabalistik dari konsekuensi kecelakaan PLTN. Tujuan penelitian adalah melakukan analisis terhadap pengaruh kondisi atmosfer berdasarkan model data input meteorologi terhadap dampak radiologi kecelakaan PWR-1000MWe yang disimulasikan pada Tapak Semenanjung Muria dan Tapak Pesisir Serang yang mempunyai kondisi meteorologi yang berbeda.

Simulasi menggunakan program PC-Cosyma dengan moda perhitungan probabilistik, dengan input data meteorologi yang dieksekusi secara cyclic dan stratified. Data meteorologi diambil setiap jam untuk jangka waktu satu tahun. Parameter meteorologi yang diambil untuk input data adalah stabilitas cuaca, arah angin, kecepatan angin dan solar radiasi dalam 16 sektor. Input data lingkungan yang diambil adalah distribusi penduduk dan data analisis produksi pertanian dan peternakan. Keluaran (output) yang dikaji adalah pengaruh dua model eksekusi meteorologi terhadap aktivitas dispersi udara dan deposisi permukaan dari lepasan Cs-137 dan I131, dosis individu jangka pendek dan jangka panjang. Simulasi dilakukan pada dua tapak yang berbeda yaitu Tapak Semenanjung Muria dan Pesisir Serang. Source term diestimasi berdasarkan postulasi dan asumsi kecelakaan parah di PWR-1000MWe [3].

\section{PC-Cosyma (Code System of Methods for Assessing Radiological Impact of Accident)}

PC-Cosyma adalah paket program untuk estimasi dan kajian terhadap dampak dari lepasan ZRA ke lingkungan akibat terjadi kecelakaan di fasilitas nuklir. Program ini dapat melakukan perhitungan secara deterministik dan probabilistik. Perhitungan deterministik dengan PC-Cosyma bekerja dengan tidak mempertimbangkan ketidakpastian, dan berasumsi bahwa ada nilai tunggal untuk semua parameter dengan melakukan pengecualian untuk kondisi atmosfer selama periode rilis dan waktu yang dibutuhkan untuk bergerak atau terdispersi. Perhitungan probalistik PC-Cosyma adalah memprediksi distribusi probabilitas dari konsekuensi saat kecelakaan terjadi di berbagai kondisi atmosfer termasuk perubahan dari kondisi selama 
terbentuknya plume. Urutan kondisi diperoleh dengan menggunakan data tentang kondisi atmosfer setiap jam selama 1 tahun. Kondisi atmosfer pada saat rilis dapat mempengaruhi prediksi semua modul dari PC-Cosyma, bukan hanya modul dispersi dan deposisi. Beberapa radionuklida terdeposisi pada tingkat yang berbeda relatif terhadap satu sama lain dalam kondisi basah dan kering. Hal ini dapat mempengaruhi kontribusi radionuklida untuk dosis dari semua jalur paparan. Waktu tempuh plume untuk jarak yang berbeda dapat mempengaruhi sejauh mana penanggulangan dapat mengurangi dosis yang diterima oleh penduduk. Oleh karena itu analisis ketidakpastian semua modul harus mempertimbangkan berbagai kemungkinan kondisi atmosfer yang dapat terjadi $[1,8-9]$.

Perhitungan deterministic PC-Cosyma dapat menghasilkan output antara lain:

- Aktivitas dispersi dan deposisi : setiap sektor dan grid

- Risiko untuk countermeasures : besarnya risiko dan luas area

- Dosis organ untuk dosis individu efektif jangka pendek dan panjang, serta dosis kolektif untuk setiap sektor dan grid

- Risiko individu dan kolektif untuk efek tunda terhadap kesehatan untuk setiap efek dan setiap grid untuk setiap jarak radius.

Perhitungan probabilistik PC-Cosyma dapat menghasilkan output antara lain:

- Aktivitas dispersi dan deposisi setiap jarak radius

- Risiko untuk countermeasures yaitu probabilitas distribusi jumlah risiko dan area terkontaminasi.

- Dosis organ untuk dosis individu efektif jangka pendek dan panjang, serta dosis kolektif dengan probabilitas distribusi dosis untuk titik titik tertentu atau untuk setiap jarak.

- Risiko individu dan kolektif untuk efek tunda terhadap kesehatan dengan probabilitas dari distribusi risiko individu untuk titik tertentu atau setiap jarak radius.

Data meteorologi pada perhitungan probabilistik adalah setiap jam $n$ pada meteorologi file data. Sedangkan model input stratified sampling melibatkan seperangkat kriteria untuk mengelompokkan urutan kondisi meteorologi yang mungkin untuk memberikan konsekuensi yang sama, dan memilih salah satu urutan (sekuensi) dari masing-masing kelompok. Jumlah sekuensi didalam pengambilan data meteorologi sama dengan jumlah jam dibagi waktu antar sekuen. Maksimum jumlah sekuen yang diijinkan di PC-Cosyma adalah 144 [1,7]. Dalam hal ini semua urutan akan mulai pada waktu hari yang sama, dan sampel yang diperoleh tidak akan mewakili berbagai kondisi dalam file data. PC-Cosyma dimaksudkan untuk perhitungan probabilistik untuk konsekuensi rilis off-site [10].

Pengambilan data setiap jam akan menghasilkan 8760 sekuensi cuaca pertahun. Dengan demikian, sekuensi memberikan konsekuensi yang sama digabungkan ke dalam kelompokkelompok. Probabilitas dihitung untuk setiap kelompok dengan rasio jumlah sekuensi dalam kelompok untuk jumlah total 8760 sekuensi. Sekuen kemudian dipilih secara acak dari masingmasing kelompok sebagai wakil, dengan probabilitas yang sesuai dari kelompok mereka. dengan menjumlahkan konsekuensi dari semua perwakilan probabilitas kelompok, konsekuensi rata-rata tahunan dapat diperoleh. Perhitungan dispersi di atmosfer menggunakan persamaan Gaussian yang sudah tersegmentasi yang dimodifikasi dari persamaan Gifford [1,8-9].

Persamaan yang digunakan untuk menghitung dispersi plume $[1,3,8]$ :

$$
X=\frac{Q}{2 \pi \sigma_{y} \sigma_{z} \mu}\left[-1 / 2\left(y / \sigma_{y}\right)^{2}\right]\left\{\exp \left[-1 / 2\left((z-H) / \sigma_{z}\right)^{2}\right]+\exp \left[-1 / 2\left((z+H) / \sigma_{z}\right)^{2}\right]\right\}
$$

dengan:

$\mathrm{X}=$ Konsentrasi di udara (chi) pada sumbu $\mathrm{x}$ searah angin $\left(\mathrm{Ci} / \mathrm{m}^{3}\right)$

$\mathrm{Q}=$ Lepasan radioaktif rata-rata yang ke luar dari cerobong $(\mathrm{Ci} / \mathrm{dt})$

$\mu \quad=$ Kecepatan angin rata-rata $(\mathrm{m} / \mathrm{dt})$ 


$$
\begin{array}{ll}
\sigma_{\mathrm{y}} & =\text { Koefisien dispersi horizontal }(\mathrm{m}) \\
\sigma_{\mathrm{z}} & =\text { Koefisien dispersi vertikal }(\mathrm{m}) \\
\mathrm{H} & =\text { Tinggi cerobong efektif } \\
\mathrm{y} & =\text { Jarak tegak lurus arah angin }(\mathrm{m}) \\
\mathrm{z} & =\text { Ketinggian dari atas tanah }(\mathrm{m})
\end{array}
$$

\section{METODOLOGI}

Model perhitungan dispersi menggunakan moda probabilistik dengan model input data meteorologi dipilih model cyclic dan stratified. Dari perhitungan pendahuluan diperoleh jumlah sekuensi optimal untuk memenuhi ketelitian kaidah perhitungan statistika adalah $\geq 70$ sekuensi, sehingga pada penelitian untuk model input cyclic dipilih waktu data 124 jam dengan sekuensi data 71 sekuen dari total 8760 jam waktu pengambilan satu tahun. Simulasi menggunakan program PC-Cosyma. Simulasi dilakukan untuk Tapak Semenanjung Muria dan Pesisir Serang. Data input meteorologi dan data spasial lingkungan menggunakan data yang disampling di dua tapak tersebut. Source term dipostulasikan kondisi severe accident dengan tujuan analisis statistika lebih terlihat pada sumber sebaran yang lebih besar. Source term yang digunakan pada penelitian ini menggunakan source term yang sudah dihitung pada PWR 1000-MWe [3,8,11].

Perhitungan aktivitas dispersi dan deposisi, serta dosis jangka pendek dan jangka panjang dilakukan dengan menggunakan data input meteorologi dengan dua moda data input yang berbeda. Moda data input meteorologi yaitu moda stratified dan moda cyclic. Kedua moda input tersebut disimulasikan dengan menggunakan source term yang sama untuk dua tapak berbeda yaitu Tapak Semenanjung Muria dan Tapak Pesisir Serang. Dengan dua tapak yang berbeda akan mendapatkan kondisi data meteorologi yang berbeda. Perhitungan dalam penelitian ini akan melibatkan dua paket data meteorologi dari dua tapak yang berbeda, dan dua model data input meteorologi untuk setiap tapak. Produk fisi yang digunakan sebagai nuklida acuan evaluasi adalah nuklida produk fisi Cs-137 dan I-131, dengan dasar pertimbangan nuklida ini mempunyai waktu paruh panjang sehingga akan memberikan dampak yang signifikan terhadap penerimaan dosis di masyarakat. Selain itu juga dari sifat mobilitas dan tingkat toksisitasnya $[12,13]$.

Alur metode perhitungan terdapat pada Gambar 1.

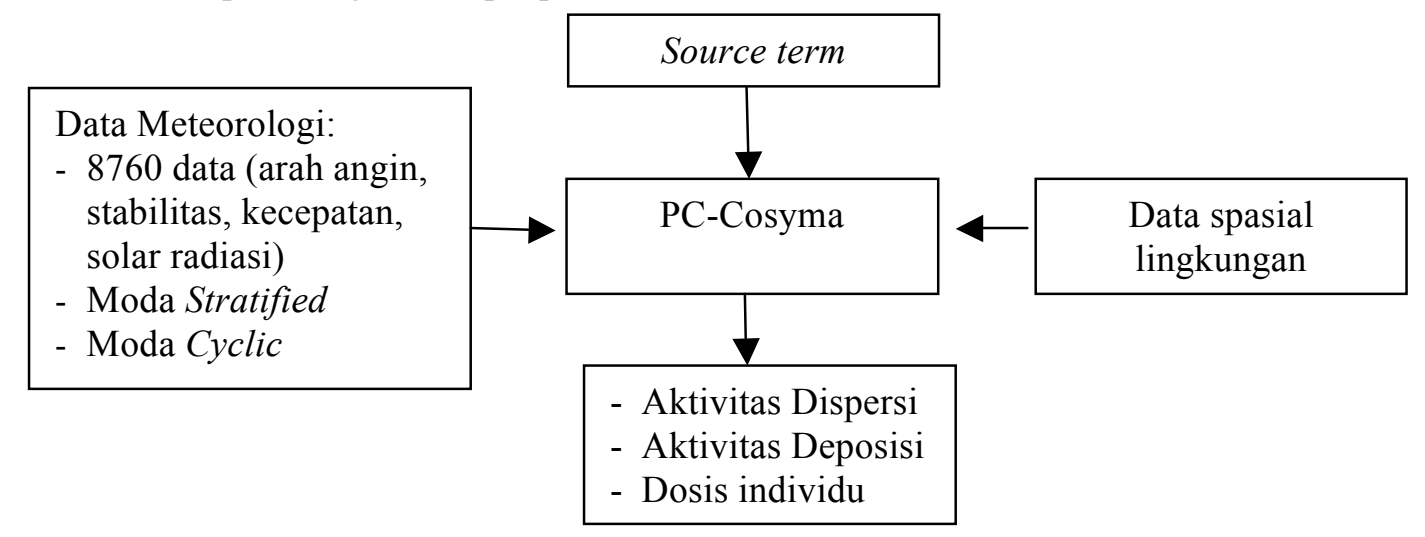

Gambar 1. Alur metode perhitungan dengan moda perhitungan probabilistik.

\section{HASIL DAN PEMBAHASAN}

Hasil perhitungan untuk Complementary cumulative distribution frequency (Ccdfs) untuk aktivitas radiasi tercantum dalam Gambar 2, dan untuk deposisi di permukaan tanah terdapat pada Gambar 3. Sedangkan Ccdfs untuk dosis individu efektif jangka pendek pada Gambar 4, dan untuk dosis jangka panjang ada di Gambar 5. Evaluasi untuk aktivitas radiasi tercantum pada Tabel 1, dan untuk dosis tercantum pada Tabel 2. 


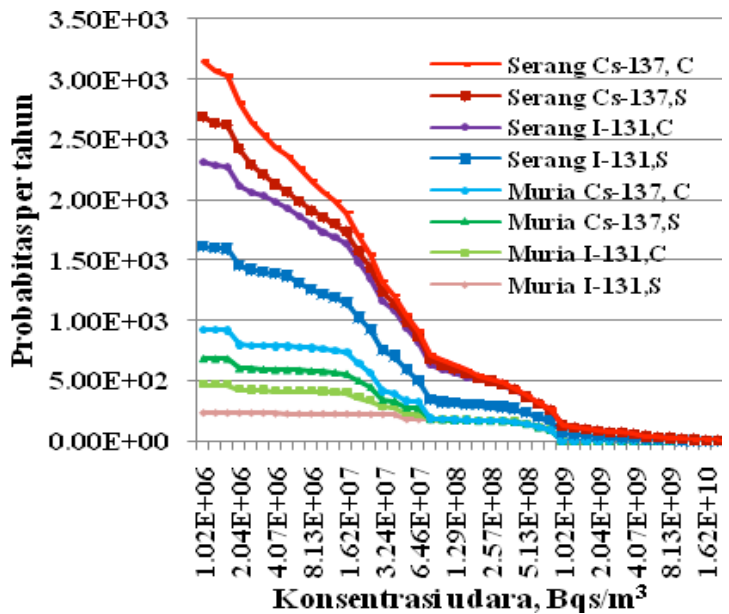

Gambar 2. Complementary cumulative distribution frequency (Ccdfs) dari konsentrasi dispersi di udara rerata pada radius $800 \mathrm{~m}$

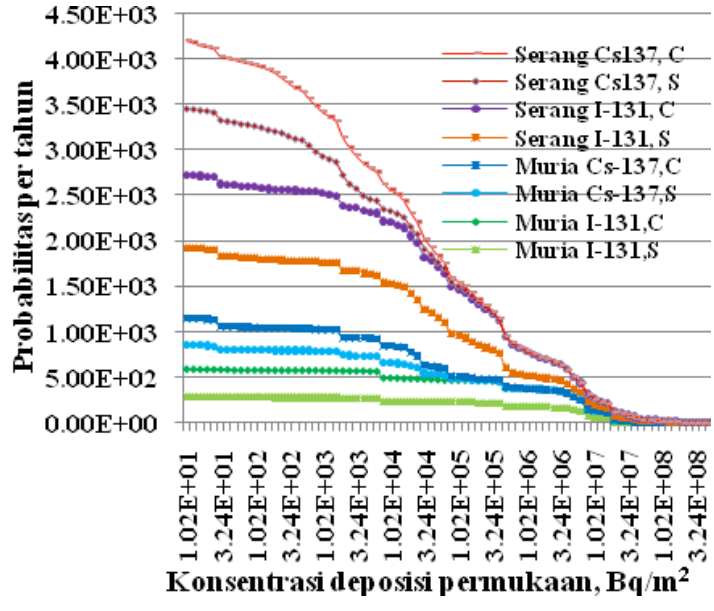

Gambar 3. Complementary cumulative distribution frequency (Ccdfs) dari konsentrasi deposisi di permukaan tanah rerata pada radius $800 \mathrm{~m}$.

Secara umum untuk konsentrasi dispersi dan deposisi pada Gambar 2 dan Gambar 3 terlihat bahwa frekuensi distribusi kumulatif (probabilitas) menurun dengan bertambahnya konsentrasi yang terdispersi atau terdeposisi. Untuk kondisi source term, tapak, dan moda data meteorologi (cyclic atau stratified) yang sama probabilitas terjadinya dispersi atau deposisi untuk nuklida produk fisi I-131 lebih kecil dibandingkan Cs-137, hal itu berkaitan dengan perbedaan besarnya source term dan sifat perilaku dari nuklida. Walaupun aktivitas source term I-131 lebih besar dibandingkan dengan Cs-137 dan sifat I-131 lebih mobil dan volatil dibandingkan dengan Cs-137, tetapi waktu paruh dan sifat toksisitas Cs-137 lebih besar dibandingkan I-131. Sedangkan untuk aktivitas deposisi di permukaan berkaitan dengan aktivitas dispersi dengan konsentrasi yang sebanding dengan kenaikan aktivitas dispersi di atmosfer.

Frekuensi distribusi kumulatif untuk konsentrasi aktivitas dispersi di udara tertinggi untuk Cs-137, Tapak Pesisir Serang, dengan model input data meteorologi cyclic. Nilai frekuensi distribusi kumulatif Cs-137 adalah 3,8E+02 untuk konsentrasi dispersi di udara sebesar $1,02 \mathrm{E}+06 \mathrm{Bqs} / \mathrm{m}^{3}$. Frekuensi distribusi kumulatif untuk konsentrasi aktivitas deposisi di permukaan tertinggi Cs-137 adalah 7,43E +02 untuk konsentrasi $1,02 \mathrm{E}+01 \mathrm{~Bq} / \mathrm{m}^{2}$ untuk Tapak Pesisir Serang dengan model input data meteorologi cyclic.

Berdasarkan tapak untuk source term, dan model data meteorologi (cyclic atau stratified) yang sama frekuensi distribusi kumulatif terjadinya dispersi atau deposisi untuk nuklida produk fisi I-131 atau Cs-137; frekuensi distribusi kumulatif konsentrasi dispersi dan deposisi lebih tinggi untuk Tapak Pesisir Serang dibandingkan Tapak Semenanjung Muria. Hal ini berkaitan dengan kondisi meteorologi Tapak Pesisir Serang memiliki nilai paremeter dispersi yang lebih tinggi dibandingkan tapak Semenanjung Muria [6].

Frekuensi distribusi kumulatif untuk konsentrasi aktivitas dispersi dan deposisi tertinggi untuk kondisi tapak, source term, dan nuklida yang sama adalah dengan menggunakan input data meteorologi dengan model input cyclic. Model input data cyclic adalah dengan melakukan pengelompokan sekuensi terhadap input data meteorologi dengan memberikan konsekuensi yang sama digabungkan ke dalam kelompok-kelompok. Probabilitas dihitung untuk setiap kelompok dengan rasio jumlah sekuensi dalam kelompok untuk jumlah total 8760 sekuensi. Sekuen kemudian dipilih secara acak dari masing-masing kelompok sebagai wakil, dengan probabilitas yang sesuai dari kelompok mereka. dengan menjumlahkan konsekuensi dari semua perwakilan probabilitas kelompok, konsekuensi rata-rata tahunan dapat diperoleh. Makin banyak kelompok sekuensi yang dipilih, probabilitas kelompok terwakili akan makin besar. Sedangkan model stratified adalah dengan mengelompokkan data input dengan strata atau level yang berbeda yang membutuhkan data input pembanding yang kemungkinan bebeda kondisinya dengan data input faktual. 
Tabel 1. Evaluasi dari konsentrasi dispersi udara

\begin{tabular}{cccccccccc}
\hline \multicolumn{7}{c}{ Evaluasi dari konsentrasi dispersi udara CS-137 $\left(\mathrm{Bq} \mathrm{s} / \mathrm{m}^{3}\right)$ di Semenanjung Muria } \\
\hline $\begin{array}{c}\text { Jarak } \\
(\mathrm{km})\end{array}$ & \multicolumn{2}{c}{ Mean } & \multicolumn{2}{c}{ Maksimum. } & \multicolumn{2}{c}{${ }^{99}$ th } & & ${ }^{95}$ th \\
& Stratified & Cyclic & Stratified & Cyclic & Stratified & Cyclic & Stratified & Cyclic \\
\cline { 2 - 10 } 0,80 & $7,34 \mathrm{E}+06$ & $7,37 \mathrm{E}+06$ & $1,98 \mathrm{E}+08$ & $1,03 \mathrm{E}+08$ & $7,76 \mathrm{E}+07$ & $7,76 \mathrm{E}+07$ & $5,01 \mathrm{E}+07$ & $5,50 \mathrm{E}+07$ \\
3,00 & $7,83 \mathrm{E}+05$ & $7,48 \mathrm{E}+05$ & $2,70 \mathrm{E}+07$ & $2,21 \mathrm{E}+07$ & $1,00 \mathrm{E}+07$ & $1,00 \mathrm{E}+07$ & $6,92 \mathrm{E}+06$ & $5,01 \mathrm{E}+06$ \\
5,00 & $3,04 \mathrm{E}+05$ & $2,94 \mathrm{E}+05$ & $1,07 \mathrm{E}+07$ & $1,04 \mathrm{E}+07$ & $3,89 \mathrm{E}+06$ & $3,89 \mathrm{E}+06$ & $2,69 \mathrm{E}+06$ & $1,82 \mathrm{E}+06$ \\
10,00 & $1,22 \mathrm{E}+05$ & $1,21 \mathrm{E}+05$ & $2,81 \mathrm{E}+06$ & $3,48 \mathrm{E}+06$ & $1,78 \mathrm{E}+06$ & $1,78 \mathrm{E}+06$ & $6,31 \mathrm{E}+05$ & $7,24 \mathrm{E}+05$ \\
20,00 & $5,55 \mathrm{E}+04$ & $5,42 \mathrm{E}+04$ & $1,49 \mathrm{E}+06$ & $1,54 \mathrm{E}+06$ & $8,91 \mathrm{E}+05$ & $8,91 \mathrm{E}+05$ & $2,04 \mathrm{E}+05$ & $2,40 \mathrm{E}+05$ \\
\hline
\end{tabular}

Evaluasi dari konsentrasi dispersi udara CS-137 (Bq s/m³) di Pesisir Serang

\begin{tabular}{rrrrrrrrr}
\hline 0,80 & $1,42 \mathrm{E}+07$ & $1,63 \mathrm{E}+07$ & $8,14 \mathrm{E}+08$ & $9,45 \mathrm{E}+08$ & $3,31 \mathrm{E}+08$ & $3,24 \mathrm{E}+08$ & $5,62 \mathrm{E}+07$ & $5,62 \mathrm{E}+07$ \\
3,00 & $5,03 \mathrm{E}+06$ & $6,46 \mathrm{E}+06$ & $2,23 \mathrm{E}+08$ & $3,06 \mathrm{E}+08$ & $7,59 \mathrm{E}+07$ & $6,92 \mathrm{E}+07$ & $2,29 \mathrm{E}+07$ & $2,82 \mathrm{E}+07$ \\
5,00 & $3,78 \mathrm{E}+06$ & $4,31 \mathrm{E}+06$ & $1,29 \mathrm{E}+08$ & $1,50 \mathrm{E}+08$ & $6,17 \mathrm{E}+07$ & $4,79 \mathrm{E}+07$ & $1,95 \mathrm{E}+07$ & $2,29 \mathrm{E}+07$ \\
10,00 & $1,17 \mathrm{E}+06$ & $1,88 \mathrm{E}+06$ & $4,36 \mathrm{E}+07$ & $3,16 \mathrm{E}+07$ & $1,55 \mathrm{E}+07$ & $2,00 \mathrm{E}+07$ & $7,76 \mathrm{E}+06$ & $1,00 \mathrm{E}+07$ \\
20,00 & $4,54 \mathrm{E}+05$ & $7,26 \mathrm{E}+05$ & $1,77 \mathrm{E}+07$ & $1,74 \mathrm{E}+07$ & $5,01 \mathrm{E}+06$ & $7,59 \mathrm{E}+06$ & $2,69 \mathrm{E}+06$ & $3,55 \mathrm{E}+06$
\end{tabular}

Evaluasi dari konsentrasi dispersi udara I-131 ( $\left.\mathrm{Bq} \mathrm{s} / \mathrm{m}^{3}\right)$ di Semenanjung Muria

\begin{tabular}{ccccccccc}
\hline 0,80 & $1,92 \mathrm{E}+08$ & $1,93 \mathrm{E}+08$ & $5,19 \mathrm{E}+09$ & $2,63 \mathrm{E}+09$ & $2,04 \mathrm{E}+09$ & $2,04 \mathrm{E}+09$ & $1,32 \mathrm{E}+09$ & $1,45 \mathrm{E}+09$ \\
3,00 & $2,03 \mathrm{E}+07$ & $1,94 \mathrm{E}+07$ & $6,88 \mathrm{E}+08$ & $5,75 \mathrm{E}+08$ & $2,63 \mathrm{E}+08$ & $2,63 \mathrm{E}+08$ & $1,78 \mathrm{E}+08$ & $1,32 \mathrm{E}+08$ \\
5,00 & $7,82 \mathrm{E}+06$ & $7,59 \mathrm{E}+06$ & $2,68 \mathrm{E}+08$ & $2,68 \mathrm{E}+08$ & $1,00 \mathrm{E}+08$ & $1,00 \mathrm{E}+08$ & $7,08 \mathrm{E}+07$ & $4,68 \mathrm{E}+07$ \\
10,00 & $3,11 \mathrm{E}+06$ & $3,10 \mathrm{E}+06$ & $7,14 \mathrm{E}+07$ & $8,86 \mathrm{E}+07$ & $4,47 \mathrm{E}+07$ & $4,47 \mathrm{E}+07$ & $1,59 \mathrm{E}+07$ & $1,86 \mathrm{E}+07$ \\
20,00 & $1,39 \mathrm{E}+06$ & $1,36 \mathrm{E}+06$ & $3,72 \mathrm{E}+07$ & $3,85 \mathrm{E}+07$ & $2,24 \mathrm{E}+07$ & $2,24 \mathrm{E}+07$ & $5,13 \mathrm{E}+06$ & $6,03 \mathrm{E}+06$
\end{tabular}

Evaluasi dari konsentrasi dispersi udara I-131 (Bq s/m³) di Pesisir Serang

\begin{tabular}{ccccccccc}
\hline 0,80 & $3,98 \mathrm{E}+08$ & $3,98 \mathrm{E}+08$ & $2,40 \mathrm{E}+10$ & $2,40 \mathrm{E}+10$ & $8,32 \mathrm{E}+09$ & $8,32 \mathrm{E}+09$ & $1,38 \mathrm{E}+09$ & $1,38 \mathrm{E}+09$ \\
3,00 & $1,42 \mathrm{E}+08$ & $1,42 \mathrm{E}+08$ & $6,96 \mathrm{E}+09$ & $6,96 \mathrm{E}+09$ & $1,78 \mathrm{E}+09$ & $1,78 \mathrm{E}+09$ & $6,31 \mathrm{E}+08$ & $6,31 \mathrm{E}+08$ \\
5,00 & $8,84 \mathrm{E}+07$ & $8,84 \mathrm{E}+07$ & $3,23 \mathrm{E}+09$ & $3,23 \mathrm{E}+09$ & $1,00 \mathrm{E}+09$ & $1,00 \mathrm{E}+09$ & $4,90 \mathrm{E}+08$ & $4,90 \mathrm{E}+08$ \\
10,00 & $3,28 \mathrm{E}+07$ & $3,28 \mathrm{E}+07$ & $5,75 \mathrm{E}+08$ & $5,75 \mathrm{E}+08$ & $3,63 \mathrm{E}+08$ & $3,63 \mathrm{E}+08$ & $1,86 \mathrm{E}+08$ & $1,86 \mathrm{E}+08$ \\
20,00 & $1,01 \mathrm{E}+07$ & $1,01 \mathrm{E}+07$ & $2,42 \mathrm{E}+08$ & $2,42 \mathrm{E}+08$ & $1,20 \mathrm{E}+08$ & $1,20 \mathrm{E}+08$ & $5,13 \mathrm{E}+07$ & $5,13 \mathrm{E}+07$ \\
\hline
\end{tabular}

Evaluasi statistika terhadap konsentrasi produk fisi yang terdispersi di udara dijelaskan dalam Tabel 1. Secara umum dari data bahwa konsentrasi menurun dengan bertambahnya jarak radius dari pusat sebaran. Tidak ada perbedaan yang signifikan (dalam orde yang sama) terhadap konsentrasi nuklida Cs-137 maupun I-131 untuk nilai rerata, nilai maksimum, maupun nilai persentil $99^{\text {th }}$ atau $95^{\text {th }}$ untuk dua model input data stratified maupun cyclic. Berbeda dengan nilai frekuensi distribusi kumulatif (probabilitas), yang menunjukkan perbedaan probabilitas untuk dua 
model input data meteorologi stratified atau cyclic. Ke dua model penggunaan input data meteorologi dihitung dengan pengulangan dan melibatkan jumlah data yang besar yang akan menguntungkan atau meningkatkan nilai-nilai statistika dengan tingkat ketelitian yang meningkat. Akhirnya perhitungan atau simulasi menggunakan input data meteorologi dengan model stratified atau cyclic tidak memberikan perbedaan yang berarti terhadap hasil akhir nilai konsentrasi yang akan dicapai.

Konsentrasi rerata tertinggi untuk produk fisi Cs-137 adalah 1,63E+07 Bqs $/ \mathrm{m}^{3}$, di Tapak Pesisir Serang dalam jarak radius daerah eksklusi $800 \mathrm{~m}$, dan penggunaan model input data cyclic. Dengan kondisi yang sama nilai maksimum Cs-137 adalah 9,45E+08 Bqs $/ \mathrm{m}^{3}$, nilai persentil $99^{\text {th }}$ adalah $3,24 \mathrm{E}+08 \mathrm{Bqs} / \mathrm{m}^{3}$, dan nilai persentil $95^{\text {th }}$ adalah $5,62 \mathrm{E}+07 \mathrm{Bqs} / \mathrm{m}^{3}$. Poduk fisi $\mathrm{I}-131$ rerata untuk kondisi yang sama adalah $3,98 \mathrm{E}+08 \mathrm{Bqs} / \mathrm{m}^{3}$, nilai maksimum $2,40 \mathrm{E}+10 \mathrm{Bqs} / \mathrm{m}^{3}$, nilai persentil $99^{\text {th }} 8,32 \mathrm{E}+09 \mathrm{Bqs} / \mathrm{m}^{3}$, dan nilai persentil $95^{\text {th }} 1,38 \mathrm{E}+09 \mathrm{Bqs} / \mathrm{m}^{3}$.

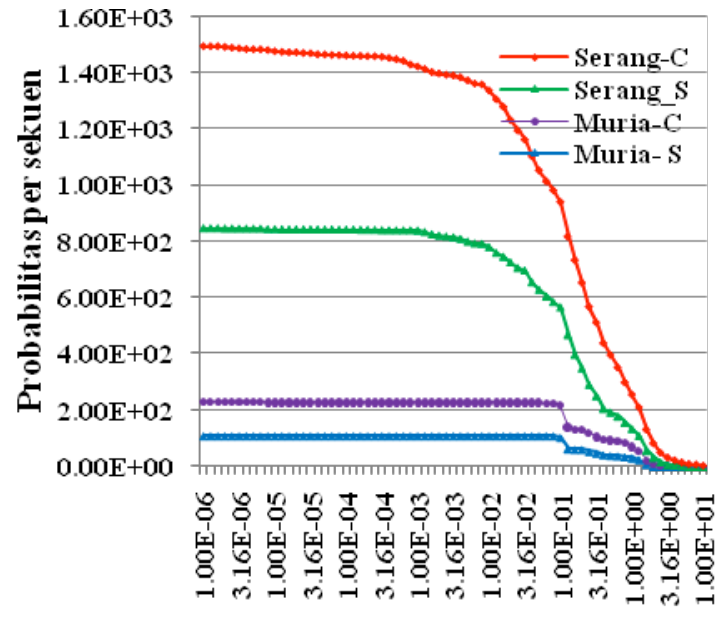

Dosis Individu jangka pendek (mSv)

Gambar 4 Complementary cumulative distribution frequency (Ccdfs) rerata dosis individu efektif jangka pendek dalam radius $800 \mathrm{~m}$.

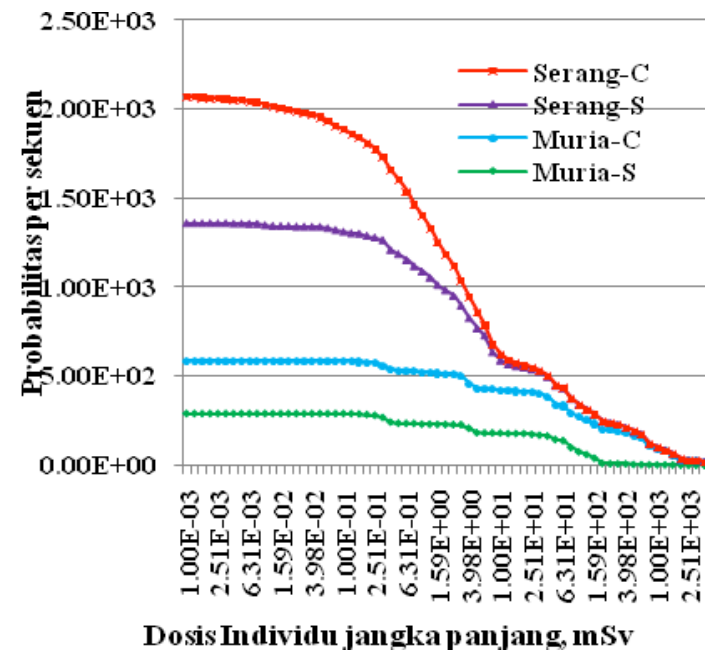

Gambar 5. Complementary cumulative distribution frequency (Ccdfs) rerata dosis individu efektif jangka panjang dalam radius $800 \mathrm{~m}$.

Gambaran Complementary cumulative distribution frequency (Ccdfs) rerata dosis individu efektif untuk jangka pendek dan jangka panjang dijelaskan pada Gambar 4 dan Gambar 5 . Besarnya nilai Ccdfs sebanding dengan nilai frekuensi kumulatif konsentrasi dispersi dan deposisi, karena penerimaan dosis bergantung pada konsentrasi dispersi udara (melalui pathway cloudshine dan groundshine) dan deposisi permukaan melalui alur foodstuff dan groundshine. Terlihat dari Gambar 4 dan 5 bahwa frekuensi distribusi kumulatif menurun dengan bertambahnya dosis individu efektif jangka pendek maupun jangka panjang. Ccdfs untuk penerimaan dosis jangka panjang dengan model input cyclic di daerah tapak dan source term yang sama lebih besar dibandingkan dengan input data model stratified. Complementary cumulative distribution frequency (Ccdfs) untuk Tapak Pesisir Serang lebih tinggi dibandingkan Tapak Semenanjung Muria.

Frekuensi distribusi kumulatif tertinggi 6,47E+02 untuk penerimaan dosis jangka pendek adalah 1,00E-06 mSv di area jarak radius $800 \mathrm{~m}$ di Tapak Pesisir Serang dengan model input meteorologi cyclic dan terendah 4,33E-02 untuk dosis 3,98E+00 mSv di area $800 \mathrm{~m}$ Tapak Semenanjung Muria dengan model input meteorologi stratified. Penerimaan dosis jangka panjang dengan frekuensi kumulatif (probabilitas) tertinggi dengan menggunakan model input cyclic, Tapak Pesir Serang dalam radius $800 \mathrm{~m}$ adalah 7,07E+02 untuk dosis 1,00E-03 mSv. Probabilitas terendah $6,06 \mathrm{E}+01$ pada dosis $1,26 \mathrm{E}+02 \mathrm{mSv}$ radius $800 \mathrm{~m}$ di Tapak Semenanjung Muria menggunakan model input stratified.

Evaluasi terhadap penerimaan dosis jangka pendek terdapat pada Tabel 2. Penerimaan dosis individu efektif jangka pendek untuk Tapak Semenanjung Muria lebih rendah dibandingkan Pesisir Serang. Penggunaan input data meteorologi dengan model cyclic 
menghasilkan perhitungan dosis lebih tinggi dibandingkan model input stratified tetapi masih dalam orde yang sama. Penerimaan dosis dengan source term dan di tapak yang sama menunjukkan kecenderungan naik sebanding dengan bertambahnya jarak radius dari sumber lepasan. Pada Tapak Pesisisir Serang dalam radius $800 \mathrm{~m}$ mendapatkan dosis rerata tertinggi 4,07E-01 mSv dengan menggunakan model input cyclic. Dosis rerata terendah di Tapak Semenanjung Muria 6,55E-02 mSv dengan model input stratified.

Tabel 2. Evaluasi dosis individu efektif jangka pendek

\begin{tabular}{ccccccccc}
\hline \multicolumn{8}{c}{ Evaluasi dosis individu efektif jangka pendek di Semenanjung Muria } \\
\hline \multicolumn{8}{c}{ Jarak } \\
$(\mathrm{km})$
\end{tabular}

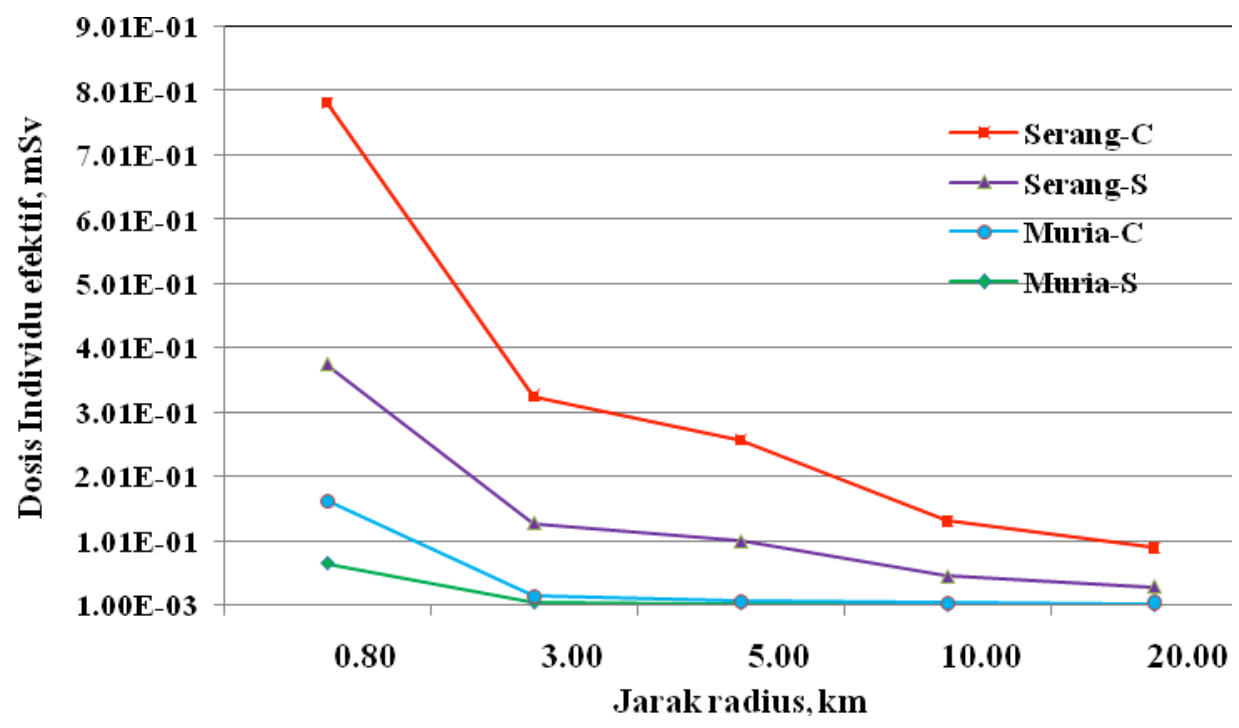

Gambar 6. Dosis individu efektif efektif jangka pendek vs jarak radius

Penerimaan dosis maksimum untuk Tapak Pesisir Serang dalam radius $800 \mathrm{~m}$ menggunakan model input data cyclic adalah $1,22 \mathrm{E}+01 \mathrm{mSv}$, dan untuk Tapak Semenanjung Muria model input data stratified adalah $4,33 \mathrm{E}+00 \mathrm{mSv}$. Dosis tertinggi untuk persentil $99^{\text {th }}$ adalah $5,01 \mathrm{E}+00 \mathrm{mSv}$ 
untuk Tapak Pesisir Serang model cyclic, terendah 2,75E $+00 \mathrm{mSv}$ untuk Tapak Semenanjung Muria model stratified. Untuk persentil $95^{\text {th }}$ dosis tertinggi di Pesisir Serang dengan model cyclic adalah 2,00E $+00 \mathrm{mSv}$, dan terendah 2,88E-01 mSv untuk tapak Semenanjung Muria dengan model stratified.

Penerimaan dosis individu efektif menggunakan dua paket input data meteorologi dari dua Tapak berbeda dan input sourceterm yang sama, dengan model cyclic atau stratified dijelaskan pada Gambar 6. Secara umum dosis menurun dengan bertambahnya jarak radius dengan garis dosis tertinggi untuk Tapak Pesisir Serang menggunakan model input data meteorologi cyclic. Garis dosis terendah ditunjukkan untuk perhitungan di Tapak Semenanjung Muria dengan model input data meteorologi stratified.

\section{KESIMPULAN}

Pengaruh kondisi atmosferik terhadap perhitungan probabilistik dampak kecelakaan PWR1000 MWe dapat diketahui dari frekuensi kumulatif (probabilitas) aktivitas dan konsekuensi radiasi di lingkungan. Frekuensi kumulatif yang diperoleh dari moda perhitungan probabilistik secara komprehensif dapat diketahui dengan melakukan simulasi menggunakan data input meteorologi dengan dua model yaitu model cyclic dan model stratified yang disimulasikan pada dua tapak dengan kondisi atmosferik yang berbeda. Hasil simulasi menyimpulkan bahwa model input cyclic di Tapak Pesisir Serang memberikan frekuensi kumulatif untuk aktivitas dan konsekuensi radiasi paling tinggi dibandingkan kombinasi model input dan kondisi atmosferik tapak lainnya. Frekuensi kumulatif terendah diperoleh dari model input stratified yang disimulasikan di Tapak Semenanjung Muria. Konsentrasi lepasan produk fisi di atmosfer mempunyai hubungan yang erat dengan kondisi meteorologi tapak pada saat terjadi lepasan.

\section{UCAPAN TERIMA KASIH}

Ucapan terima kasih ditujukan untuk saudara Sumantri, AMd yang telah membantu menyiapkan input data demi kelancaran perhitungan yang dilakukan dalam penelitian ini.

\section{DAFTAR PUSTAKA}

1. Jones $\mathrm{J}$ A., et al, Probabilistic accident consequence uncertainty assessments using COSYMA: Methodology and processing techniques. EUR 18827 and FZKA 6313; 2000.

2. Prasad M. H., et al, Level-1, -2 and -3 PSA for AHWR. Nuclear Engineering and Design 2011; 241: 3256- 3269

3. Udiyani P.M., Kuntjoro S., Tjahyani DTS, PSA Level 3 dan implementasinya pada kajian keselamatan PWR. J. Tek. Reaktor Nukl. 2014;16 (1): 31-43

4. Simon-Cornu, M., et al, Evaluating variability and uncertainty in radiological impact assessment using SYMBIOSE. Journal of Environmental Radioactivity 2015; 139: 91-102

5. Rolph G.D., Ngan F., Draxler R.R, Modeling the fallout from stabilized nuclear clouds using the HYSPLIT atmospheric dispersion model. Journal of Environmental Radioactivity 2014; 136: 41-55

6. Udiyani P.M., Widodo S., Penentuan koefisien dispersi atmosferik untuk analisis kecelakaan reaktor PWR di Indonesia, J. Tek. Reaktor Nukl. 2012; 14 (2): 121-132

7. Furlan C., et al, The role of clouds in improving the regression model for hourly values of diffuse solar radiation. Applied Energy 2012; 92: 240-254

8. Zhao Y., Zhang L., Tong J., Development of rapid atmospheric source term estimation system for AP1000 nuclear power plant. Progress in Nuclear Energy 2015: 81: 264-275

9. Hyojoon J., et al, Radiological dose assessments according to dilution characteristics of radioactive materials in nuclear sites. Annals of Nuclear Energy 2014; 3: 261-267 
10. Cao J.Z., et al, Adaptation of COSYMA and assessment of accident consequences for Daya Bay nuclear power plant in China. Journal of Environmental Radioactivity 2000; 48: $265-277$

11. Varun H.C., Kumar S., Velusamy K., Probabilistic safety assessment of multi-unit nuclear power plant sites- An integrated approach. Journal of Loss Prevention in the Process Industries 2014;32: 52-62

12. Tracy B.L. et al, The sensitivity of different environments to radioactive contamination. Journal of Environmental Radioactivity 2013; 122: 1-8

13. Vandenhove H., et al, Predicting the environmental risks of radioactive discharges from Belgian nuclear power plants. Journal of Environmental Radioactivity 2013;126: 61-76 